\title{
PENGARUH PERBEDAAN KONSENTRASI GARAM TERHADAP ASAM GLUTAMAT TERASI UDANG REBON (Acetes sp.)
}

\author{
Rizki Wisnu Murti, Sumardianto, Lukita Purnamayati* \\ Departemen Teknologi Hasil Perikanan, Fakultas Perikanan dan Ilmu Kelautan Universitas Diponegoro \\ Jalan Prof. Soedarto, SH, Tembalang, Semarang, Jawa Tengah-50275 \\ Diterima: 05 November 2020/Disetujui: 17 Maret 2021 \\ ^Korespondensi: lukita.purnamayati@live.undip.ac.id
}

Cara sitasi: Murti RW, Sumardianto, Purnamayati L. Pengaruh perbedaan konsentrasi garam terhadap asam glutamat terasi udang rebon (Acetes sp.). Jurnal Pengolahan Hasil Perikanan Indonesia. 24(1): 50-59.

\begin{abstract}
Abstrak
Udang rebon pada umumnya digunakan sebagai bahan baku produk produk penyedap rasa, antara lain terasi udang, petis, dan diolah menjadi rebon kering. Terasi udang dibuat melalui proses fermentasi garam. Fermentasi garam akan men-imbulkan rasa gurih, karena komponen pada udang rebon mengalami pemecahan akibat aktivitas enzim protease. Tujuan penelitian ini adalah untuk menentukan karakteristik terasi berdasarkan perbedaan konsentrasi garam. Perlakuan pada penelitian adalah perbedaan konsentrasi garam dengan konsentrasi 2, 8, dan 14\%. Parameter yang diamati adalah TPC BAL, pH, aw, kadar garam, asam glutamat, kadar air, dan organoleptik. Data parametrik dianalisis dengan uji ANOVA dan dilanjut-kan uji BNJ, sedangkan data non-parametrik dianalisis dengan Kruskal-Wallis dan dilanjutkan dengan uji lanjut Mann-Whitney. Hasil penelitian menunjukkan bahwa terasi udang rebon dengan konsentrasi garam 2, 8, dan $14 \%$ mempunyai perbedaan yang nyata $(\mathrm{p}<5 \%)$ terhadap kadar garam, asam glutamat dan kadar air namun tidak mempunyai perbedaan yang nyata $(\mathrm{p}>5 \%)$ terhadap $\mathrm{pH}$ dan aw. Formulasi terasi udang rebon terbaik pada penelitian ini dengan penambahan garam $2 \%$ dinilai dari asam glutamat $13,68 \% \pm 0,10$ dan uji organoleptik dengan selang kepercayaan $8,61<\mu<8,81$.
\end{abstract}

Kata kunci: fermentasi, garam, glutamat, terasi, udang rebon

\section{The Effect of Salt Concentration on Glutamic Acid Content of Mauxia Shrimp (Acetes sp.) Paste}

\begin{abstract}
Mauxia shrimp (Acetes sp.) is generally used as raw material for flavoring products in shrimp paste, paste, or processed into dried shrimp. Shrimp paste is produced using salt fermentation. During fermentation, savory taste is produced as a result of component breakdown due to the activity of the protease enzyme. The purpose of this study was to determine the effect of salt concentration on characteristics of the shrimp paste. Three salt concentrations were used including 2, 8, and 14\%. The pa-rameters observed were TPC lactic acid bacteria, $\mathrm{pH}$, aw, salt content, glutamic acid, water content and organoleptic. Paramet-ric data were analyzed using ANOVA test and continued with Tukey's HSD test, while non-parametric data were analyzed by Kruskal-Wallis and continued with Mann-Whitney test. The results showed that salt concentration had a significant difference $(\mathrm{p}<0.05)$ on the salt, glutamic acid and water content of the shrimp paste but did not have a significant difference ( $\mathrm{p}>0.05)$ to-wards $\mathrm{pH}$ and aw. Addition of $2 \%$ salt was observed producing optimum shrimp paste with glutamic acid $13.68 \% \pm 0.10$ and or-ganoleptic test with a confidence interval of $8.61<\mu<8.81$.
\end{abstract}

Keyword: fermentation, glutamate, rebon shrimp, salt, shrimp paste 


\section{PENDAHULUAN}

Udang rebon mempunyai panjang sekitar 1-1,5 cm dari kelompok Crustacea dengan nama spesies Acetes sp. Akbar et al. (2013) menyatakan bahwa udang famili Sergestidae seperti udang rebon pada umumnya bertelur di laut, sedangkan dewasa di kawasan muara. Aprodita (2018) menyatakan bahwa pada 100 $\mathrm{g}$ rebon kering terdapat 59,4 g protein, 3,6 g lemak, kalsium $2.306 \mathrm{mg}$, fosfor $625 \mathrm{~g}$, dan zat besi sebesar 21,4 g. Pemanfaatan udang rebon pada umumnya digunakan sebagai bahan baku produk penyedap rasa, antara lain terasi udang, petis, dan diolah menjadi rebon kering yang memiliki rasa yang cukup gurih. Namun, yang paling umum, udang rebon dimanfaatkan sebagai terasi udang. Ukhty et al. (2017) menyatakan bahwa terasi merupakan produk fermentasi secara sederhana, prosesnya melalui penambahan garam dan disimpan dalam kondisi tertutup dengan waktu tertentu.

Garam merupakan produk pemberi rasa asin. Garam yang umum dikenal adalah $\mathrm{NaCl}$ yang diproduksi dari air laut. Bentuk alami garam yaitu kristal. Garam memiliki banyak fungsi, salah satunya adalah pada proses fermentasi, yaitu sebagai pengontrol fermentasi, bahan pengawet, dan memberikan pengaruh cita rasa pada produk. Thariq et al. (2014) menyatakan bahwa garam merupakan bahan yang dapat mencegah pertumbuhan bakteri patogen dan bakteri pembusuk. Konsentrasi garam yang digunakan dalam fermentasi sangat menentukan mutu dari terasi. Hal tersebut terjadi karena pertumbuhan bakteri yang tahan garam memengaruhi mutu produk fermentasi. Anggo et al. (2014) menyatakan bahwa garam mampu membentuk kondisi fermentasi tertentu yang membantu pertumbuhan mikroorganisme yang bersifat halotoleran (tahan garam) dan memicu reaksi yang menghasilkan karakteristik tertentu pada terasi yang dihasilkan.

Fermentasi terasi udang rebon menghasilkan aroma khas dan rasa gurih. Timbulnya rasa gurih pada terasi udang rebon disebabkan karena kandungan protein yang tinggi, terutama asam glutamat. Tingginya kandungan asam glutamat tersebut menyebabkan terasi dapat digunakan untuk penyedap rasa alami. Anggo et al. (2014) menyatakan bahwa proses fermentasi akan memecah asam amino dari bahan baku melalui aktivitas enzim menjadi asam glutamat. Asam glutamat tersebut yang menyebabkan rasa gurih. Semakin tinggi aktivitas enzim proteolitik saat proses fermentasi, akan menghasilkan asam amino yang tinggi pula. Terasi dengan garam yang banyak akan menghambat aktivitas enzim proteolitik, sehingga rasa gurih yang ditimbulkan akan semakin berkurang. Fungsi lain garam dalam fermentasi yaitu mampu menarik air dalam suatu bahan. Selain itu garam juga dapat menghambat kerja enzim proteolitik dalam menghidrolisis karbohidrat, protein, dan lemak sehingga kemampuan menghasilkan molekul sederhana maupun senyawa-senyawa yang mudah menguap terhambat (Majid et al. 2014). Kondisi tersebut akan berpengaruh terhadap karakteristik terasi yang dihasilkan.

Penelitian mengenai terasi udang rebon telah banyak dilakukan. Sanjaya et al. (2016) menambahkan garam $15 \%$ pada proses fermentasi terasi, menghasilkan terasi dengan kadar protein sebesar 10,80\%. Anggo et al. (2014) menambahkan garam sebanyak $2 \%$ menghasilkan terasi dengan kandungan protein $62,45 \%$ dan asam glutamat tertinggi yaitu 6,56\%. Aristyan et al. (2014) juga menambahkan bahwa penggunaan konsentrasi garam 15\% menghasilkan terasi dengan karakteristik organoleptik yang disukai panelis dari segi kenampakan, bau, rasa, dan tekstur, sedangkan Ukhty et al. (2017) menghasilkan terasi udang rebon dengan asam glutamat sebesar 22,63\% dengan menggunakan konsentrasi garam $20 \%$. Berdasarkan penelitian terdahulu dapat disimpulkan bahwa penggunaan konsentrasi garam yang berbeda dapat menghasilkan terasi dengan karakteristik yang berbeda pula. Oleh karena itu, tujuan dari penelitian ini adalah untuk mengetahui pengaruh kadar garam yang berbeda terhadap karakteristik terasi udang rebon yang dihasilkan dan untuk menentukan konsentrasi garam terbaik berdasarkan karakteristik terasi udang rebon yang diperoleh. 


\section{BAHAN DAN METODE Bahan dan Alat}

Bahan utama dalam penelitian ini adalah udang rebon segar yang diperoleh dari perairan payau di Desa Margolinduk Demak, garam krosok yang diperoleh dari produsen garam di Rembang, $\mathrm{AgNO}_{3}$ (Merck), kalium kromat (Merck), akuades, agar MRS (Merck), $\mathrm{NaCl}$ pro analis (Merck), alkohol 70\% (Onemed), ninhidrin (Merck), dan etanol (Merck). Alat yang digunakan dalam penelitian ini yaitu alat penumbuk manual, gelas ukur dan gelas beaker (Iwaki), tabung reaksi (Iwaki), mikropipet, bluetip, timbangan analitik (Ohaus, China), cawan, oven listrik (Binder, Jerman), $\mathrm{pH}$ meter (Adwa, Hungaria), Aw meter (Rotronic, Swiss), spektrofotometer (Shimadzu, Jepang), Inkubator (Memmert, Jerman) dan petridish (Pyrex).

\section{Metode Penelitian}

Proses pembuatan terasi udang rebon pada penelitian ini mengacu pada Rahmayati et al. (2014), yang dimodifikasi yaitu udang rebon segar dilakukan penjemuran pertama sampai setengah kering, kemudian ditumbuk dan ditambahkan garam dengan konsentrasi yang berbeda yaitu 2\% (A), 8\% (B), dan 14\% (C). Setelah itu adonan terasi dilakukan penjemuran kedua, kemudian ditumbuk sampai halus. Kemudian adonan terasi dilakukan penjemuran yang ketiga sampai kering. Adonan terasi kemudian dicetak berbentuk balok dengan ukuran 10x4x4 cm dan dikemas dengan daun jati. Terasi yang telah dikemas kemudian dilakukan fermentasi selama 30 hari.

\section{Sensori terasi (BSN 2016)}

Pengujian mutu sensori terasi dilakukan berdasarkan score sheet pada SNI 2716: 2016. Prosedur pengujian mutu sensorik pada produk terasi sampel diletakan pada wadah dan diberi kode di setiap sampel sesuai perlakuan. Pengujian ini menggunakan 30 panelis semi terlatih.

\section{Pengujian kadar air (BSN 2006)}

Kadar air terasi dianalisis dengan memanaskan sampel pada suhu $105^{\circ} \mathrm{C}$. Cawan kosong dimasukkan ke dalam oven selama 2 jam, kemudian dimasukkan ke dalam desikator sampai mencapai suhu ruang dan ditimbang (A). Sampel sebanyak $5 \mathrm{~g}$ dimasukkan ke dalam cawan dan ditimbang (B). Cawan yang telah berisi sampel dimasukkan ke dalam oven dengan suhu $105{ }^{\circ} \mathrm{C}$ selama 24 jam. Cawan berisi sampel kering ditimbang (C). Kadar air dihitung dengan menggunakan rumus:

$\%$ kadar air $=\frac{\text { B-C }}{\text { B-A }} \times 100 \%$

Keterangan:

A=berat cawan $(\mathrm{g})$;

$\mathrm{B}=$ berat (cawan+sampel) sebelum dioven $(\mathrm{g})$;

$\mathrm{C}=$ berat (cawan+sampel) sesudah dioven $(\mathrm{g})$.

\section{Pengujian $a_{w}$ (Putri et al. 2018)}

Pengujian aw dilakukan menggunakan alat $a_{w}$ meter (Rotronic, Singapura). Alat $a_{w}$ meter dilakukan proses kalibrasi terlebih dahulu sampai netral. Sampel sebanyak $5 \mathrm{~g}$ dimasukkan ke dalam a meter sampai skala yang terdapat pada $\mathrm{a}_{\mathrm{w}}$ meter stabil.

\section{Pengujian pH (AOAC 2005)}

Terasi sebanyak $10 \mathrm{~g}$ dan ditambahkan $100 \mathrm{~mL}$ akuades kemudian dihomogenisasi dengan mengaduk sampel sampai larut menggunakan pengaduk. Pengukuran $\mathrm{pH}$ dilakukan dengan mencelupkan $\mathrm{pH}$ meter yang telah dikalibrasi ke larutan berisi sampel dan dicatat hasilnya.

\section{Pengujian asam \\ (Khokani et al. 2012)}

glutamat

Sampel ditimbang sebanyak $1 \mathrm{~g}$ dilarutkan ke dalam $100 \mathrm{~mL}$ akuabides. Kemudian dibuat larutan standar dengan 5 konsentrasi yaitu 0,2 ; 0,$4 ; 0,6 ; 0,8 ; 1,0 \mathrm{~mL}$. Selanjutnya konsentrasi diambil sebanyak $2 \mathrm{~mL}$ dan ditambahkan ninhidin $1 \mathrm{~mL}$ dan dipanaskan di waterbath selama 20 menit sampai larutan berwarna ungu. Sampel didinginkan selama 15 menit dan ditambahkan etanol $80 \%$ dan di-vortex hingga homogen. Cairan sampel didiamkan selama 10 menit lalu diukur absorbansinya menggunakan alat spektrofotometer tipe spectronix 200+ pada panjang gelombang $570 \mathrm{~nm}$. Diperoleh data hasil uji untuk menentukan asam glutamat pada sampel rumus $\mathrm{X}=\mathrm{y}-\mathrm{b} / \mathrm{a}$. 
Pengujian TPC BAL (Joni et al. 2018)

Sampel terasi ditimbang sebanyak $10 \mathrm{~g}$. Pembuatan media agar MRS yaitu dengan mencampurkan $2 \mathrm{~L} \mathrm{NaCl}$ pro analis dengan $124 \mathrm{~g}$ agar MRS. Media tersebut dipanaskan di atas hotplate sampai mendidih. Setelah mendidih, media ditutup menggunakan kapas yang dilapisi kertas aluminium dan disterilkan menggunakan autoklaf pada suhu $121^{\circ} \mathrm{C}$ selama 15 menit dengan tekanan $1 \mathrm{~atm}$. Proses pengenceran yang digunakan yaitu 10-1 sampai 10-7 dan sampel dimasukkan ke pengenceran 10-4 sampai 10-7 dan ditanam di cawan petri lalu diinkubasi. Setelah diperoleh jumlah koloni dari setiap pengenceran, selanjutnya dihitung total bakteri asam laktat yang tumbuh dengan cara mengalikan jumlah koloni dengan satu per faktor pengenceran yang dipakai. Syarat koloni yang dapat dihitung yaitu antara 25-250. Satuan yang digunakan untuk penghitungan jumlah bakteri adalah $\mathrm{cfu} / \mathrm{mL}$.

\section{Pengujian kadar garam (AOAC 2005)}

Penentuan kadar garam mengacu dari metode Mohr atau titrasi ion korida dengan perak. Sampel sebanyak $5 \mathrm{~g}$ dimasukkan ke dalam cawan porselen dan dilakukan proses pengabuan menggunakan tanur pada suhu $500{ }^{\circ} \mathrm{C}$ selama 6 jam. Setelah proses pengabuan, sampel dimasukkan ke labu ukur dan ditambahkan akuades sampai tanda tera. Abu yang larut disaring dengan kertas saring. Sebanyak $10 \mathrm{~mL}$ filtrat dimasukkan ke dalam erlenmeyer $250 \mathrm{~mL}$, lalu ditambahkan 5 tetes indikator $\mathrm{K}_{2} \mathrm{CrO}_{4} 5 \%$ dan titrasi menggunakan $\mathrm{AgNO}_{3} 0,1 \mathrm{~N}$ sampai terbentuk warna merah bata atau jingga.

\section{Analisis Data}

Analisis data menggunakan metode rancangan acak lengkap (RAL). Data parametrik dianalisis menggunakan analisis sidik ragam (ANOVA) meliputi TPC BAL, $\mathrm{pH}, \mathrm{a}_{\mathrm{w}}$, kadar garam, asam glutamat, dan kadar air. Apabila perlakuan menunjukan pengaruh $(p<5 \%)$ maka dilanjutkan dengan uji BNJ. Analisis data non-parametrik menggunakan Kruskal-Wallis untuk mengetahui perbedaan perlakuan memberikan pengaruh $(p<5 \%)$ atau tidak $(p>5 \%)$. Apabila perbedaan perlakuan menunjukkan pengaruh, maka dilanjutkan dengan uji Mann Whitney.

\section{HASIL DAN PEMBAHASAN Kadar Garam}

Nilai kadar garam pada terasi udang rebon yang diberi perlakuan perbedaan konsentrasi garam dengan konsentrasi garam yang berbeda menunjukkan hasil yang berbeda nyata pada perlakuan penambahan garam $2 \%$ dan $8 \%$, sedangkan perlakuan penambahan garam $8 \%$ dan $14 \%$ tidak berbeda nyata. Kadar garam terendah terdapat pada terasi dengan penambahan konsentrasi garam 2\% yaitu $8,35 \%$ (Table 1). Kadar garam mengalami peningkatan pada terasi pada penambahan konsentrasi garam 8\% dan 14\% yaitu masing-masing 15,33\% dan 16,87\%. Hasil kadar garam pada penelitian ini sesuai dengan SNI terasi udang dengan nomor SNI 2716: 2016, bahwa kadar garam terasi udang berkisar antara 12\%-20\% (BSN 2016).

Garam memiliki peranan penting pada proses fermentasi karena dapat memberikan cita rasa, pengontrol fermentasi, dan menghambat bakteri bakteri pembusuk yang dapat tumbuh. Hasil pada penelitian ini berbanding terbalik dengan Sanjaya et al. (2016), yaitu terasi mengalami penurunan kadar garam. Penurunan kadar garam terjadi karena digunakan oleh bakteri tahan garam untuk tumbuh. Hasil yang sama juga ditunjukkan oleh Karim et al. (2014). Terasi yang dibuat dengan menambahkan garam dengan konsentrasi $2 \%$ mengalami penurunan kadar garam. Garam mengandung senyawa kompleks $\mathrm{NaCl}$ yang mengalami ionisasi menjadi ion $\mathrm{Na}^{+}$dan $\mathrm{Cl}^{-}$yang dibutuhkan untuk pertumbuhan bakteri asam laktat. Hal ini akan menyebabkan penurunan kadar garam pada terasi. Hasil yang berbeda pada penelitian ini diduga disebabkan oleh kurangnya waktu fermentasi sehingga bakteri halofilik belum cukup menggunakan garam untuk tumbuh sehingga berpengaruh terhadap kadar garam pada terasi yang dihasilkan.

Tingginya kadar garam pada terasi berpengaruh terhadap kandungan nutrisi terasi terutama pada produksi asam glutamat. Kristianawati et al. (2014) menyatakan bahwa konsentrasi garam berpengaruh terhadap 
Table 1 Characteristics of Rebon Shrimp Paste

\begin{tabular}{lrrr}
\hline \multicolumn{1}{c}{ Parameter } & \multicolumn{1}{c}{$\mathrm{A}$} & \multicolumn{1}{c}{$\mathrm{B}$} & \multicolumn{1}{c}{$\mathrm{C}$} \\
\hline Salt $(\%)$ & $8.35 \pm 0.40^{\mathrm{a}}$ & $15.33 \pm 0.80^{\mathrm{b}}$ & $16.87 \pm 0.50^{\mathrm{b}}$ \\
TPC BAL $(\log \mathrm{cfu} / \mathrm{mL})$ & $<10$ & $<10$ & $<10$ \\
$\mathrm{a}_{\mathrm{w}}$ & $0.66 \pm 0.02^{\mathrm{a}}$ & $0.65 \pm 0.03^{\mathrm{a}}$ & $0.63 \pm 0.00^{\mathrm{a}}$ \\
$\mathrm{pH}$ & $6.37 \pm 0.07^{\mathrm{a}}$ & $6.34 \pm 0.06^{\mathrm{a}}$ & $6.29 \pm 0.07^{\mathrm{a}}$ \\
Glutamic Acid (\%) & $13.68 \pm 0.10^{\mathrm{a}}$ & $9.01 \pm 0.12^{\mathrm{b}}$ & $5.70 \pm 0.10^{\mathrm{c}}$ \\
Moisture (\%) & $38.42 \pm 0.70^{\mathrm{a}}$ & $36.34 \pm 1.30^{\mathrm{ab}}$ & $35.10 \pm 1.60^{\mathrm{b}}$ \\
\hline
\end{tabular}

aktivitas proteolitik. Secara umum, aktivitas enzim akan menurun dengan naiknya kadar garam yang menyebabkan salting out. Diduga proses salting out tersebut menyebabkan enzim mengalami denaturasi akibat molekul air hilang dari molekul proteinase sehingga menyebabkan agregasi pada enzim tersebut. Hal ini menyebabkan rendahnya kandungan asam glutamat pada terasi yang dihasilkan.

\section{TPC BAL}

Hasil yang diperoleh dari pengujian TPC BAL (Table 1) menunjukkan jumlah bakteri asam laktat yang tidak berbeda nyata. Hasil menunjukkan bakteri asam laktat tidak tumbuh optimal pada terasi yang dihasilkan. Proses fermentasi pada terasi digantikan dengan enzim yang terkandung dalam udang rebon, karena bakteri asam laktat yang tidak tumbuh dengan baik. Pertumbuhan bakteri asam laktat yang belum optimal ini dipengaruhi oleh kurang lamanya waktu fermentasi. Hasil pada penelitian ini sesuai dengan penelitian Sumardianto et al. (2019) yang menghasilkan pertumbuhan bakteri asam laktat pada terasi tidak optimal karena waktu fermentasi yang singkat sehingga fermentasi terjadi karena hidrolisis yang disebabkan enzim. Pertumbuhan bakteri asam laktat juga berhubungan dengan kadar garam. Penggunaaan garam pada proses fermentasi terasi dapat memengaruhi pertumbuhan bakteri asam laktat. Aristyan et al. (2014) menyatakan semakin tinggi konsentrasi garam pada terasi justru menurunkan pertumbuhan bakteri halofilik, termasuk bakteri asam laktat. Tingginya kadar garam menyebabkan penurunan $\mathrm{a}_{\mathrm{w}}$ terasi yang menghambat pertumbuhan bakteri asam laktat. Bakteri asam laktat dapat tumbuh optimal pada $\mathrm{a}_{\mathrm{w}} 0,75$.

\section{Aktivitas Air $\left(a_{w}\right)$}

Hasil yang diperoleh dari nilai aw (Table 1) pada terasi udang rebon dengan penambahan konsentrasi garam yang berbeda yaitu berkisar antara 0,63-0,66. Nilai $a_{w}$ pada penelitian ini tidak berbeda nyata. Nilai $\mathrm{a}_{\mathrm{w}}$ tersebut masih dibawah 0,75 sehingga mikroba termasuk bakteri asam laktat tidak dapat tumbuh. Menurut Karim et al. (2014), peningkatan penambahan garam pada proses fermentasi menyebabkan meningkatnya tekanan osmotik pada air sehingga pertumbuhan mikroorganisme akan terhambat. Penambahan garam akan menurunkan nilai $\mathrm{a}_{\mathrm{w}}$ dan dapat menyebabkan semakin lamanya pertumbuhan bakteri menuju fase lamban (lag phase). Kondisi ini menyebabkan bakteri akan mengalami kematian sebelum terjadi fase kematian bakteri dan menyebabkan produktivitas berkurang ketika berada pada awal fase statis.

Nilai $a_{w}$ di dalam bahan pangan dapat memengaruhi daya awet. Nilai $\mathrm{a}_{\mathrm{w}}$ merupakan air bebas yang digunakan mikroorganisme untuk tumbuh dan berkembang biak. Penggunaan garam pada pembuatan terasi udang rebon dapat menekan nilai $\mathrm{a}_{\mathrm{w}}$ sehingga mampu memperpanjang daya simpan dari terasi udang rebon yang dihasilkan. Hasil penelitian ini lebih rendah dibandingkan dengan penelitian Rahmayati et al. (2014) yaitu nilai $\mathrm{a}_{\mathrm{w}}$ terasi berkisar antara 0,78-0,74.

\section{Nilai $\mathrm{pH}$}

Hasil nilai $\mathrm{pH}$ (Table 1) terasi udang rebon dengan penambahan konsentrasi garam yang berbeda menunjukkan hasil yang tidak berbeda nyata dengan nilai berkisar 6,29-6,37. Nilai $\mathrm{pH}$ terasi tersebut mendekati 7 sehingga termasuk ke dalam $\mathrm{pH}$ netral. Hal ini menunjukkan bahwa proses fermentasi 
belum cukup menumbuhkan bakteri asam laktat yang mampu mengubah komponen bahan baku menjadi asam laktat yang dapat menurunkan pH. Yuliana (2007) menyatakan bahwa bakteri asam laktat mampu mendegradasi karbohidrat menjadi asamasam volatil sehingga $\mathrm{pH}$ produk menurun. Ukhty et al. (2017) menambahkan bahwa terasi memiliki pH 6 ketika awal pembuatan. $\mathrm{pH}$ akan naik menjadi 6,5 seiring dilakukan proses fermentasi. $\mathrm{pH}$ akan turun menjadi 4,5 setelah proses fermentasi selesai dan menghambat pertumbuhan mikroorganisme fermentasi. Nilai $\mathrm{pH}$ pada penelitian ini lebih tinggi dibandingkan dengan penelitian Majid et al. (2014) yaitu nilai pH terasi berkisar antara 6,62-0,52. Hasil nilai $\mathrm{pH}$ yang tidak berbeda nyata pada penelitian ini juga diduga dikarenakan bahan baku yang digunakan. Menurut Anggo et al. (2014), penggunaan bahan baku berpengaruh terhadap $\mathrm{pH}$ terasi yang dihasilkan. Bahan baku rebon kering menyebabkan perubahan $\mathrm{pH}$ karena rebon kondisi kering telah mengalami penyimpanan, sehingga proses enzimatis dan bakteriologis akan terganggu seiring dengan lamanya waktu penyimpanan.

\section{Asam Glutamat}

Hasil uji asam glutamat pada terasi udang rebon dengan perlakuan perbedaan konsentrasi garam 2, 8, dan 14\%, diperoleh hasil terbaik yaitu pada konsentrasi $2 \%$ dengan kandungan asam glutamat sebesar 13,68\%. Hasil terendah diperoleh dari konsentrasi 14\% dengan hasil sebesar 5,70\% (Table 1). Hasil ini menunjukkan bahwa penambahan konsentrasi garam yang lebih tinggi akan menghasilkan kandungan asam glutamat yang rendah. Kandungan asam glutamat berhubungan dengan pertumbuhan bakteri asam laktat dan jumlah protein pada bahan baku yang digunakan. Wenno dan Loppies (2019) menyatakan bahwa bakteri asam laktat yang tumbuh selama proses fermentasi adalah bakteri asam laktat yang bersifat proteolitik yang mampu mendegradasi protein menjadi peptida dan asam amino yang berkontribusi pada rasa produk. Aktivitas proteolitik terjadi karena adanya proses enzimatik dari bakteri asam laktat. Romadhon et al. (2018) menyatakan bahwa kandungan protein pada udang rebon berpengaruh terhadap asam glutamat yang dihasilkan selama proses fermentasi. Kandungan protein udang rebon yang tinggi akan menghasilkan asam glutamat yang tinggi pula. Pada penelitian ini, terasi mempunyai kadar garam yang tinggi justru menurunkan pertumbuhan bakteri asam laktat, sehingga dengan penambahan garam konsentrasi tinggi justru menghasilkan asam glutamat yang rendah.

Hasil pada penelitian ini sesuai dengan penelitian Puspita et al. (2019), bahwa penurunan kadar asam glutamat pada bekasam ikan lele disebabkan tingginya konsentrasi garam yang digunakan. Tingginya konsentrasi garam mampu menurunkan aktivitas bakteri proteolitik dalam memecah protein menjadi asam-asam amino terutama asam glutamat, sehingga kandungan asam glutamat menurun seiring dengan meningkatnya penambahan konsentrasi garam. Hasil penelitian ini lebih tinggi dibandingkan penelitian Thariq et al. (2014), yaitu terasi dengan penambahan garam $40 \%$ menghasilkan asam glutamat yang rendah yaitu 3,80\%. Hal ini menunjukkan bahwa tingginya konsentrasi garam berpengaruh terhadap kandungan asam glutamat pada produk terasi yang dihasilkan.

\section{Kadar Air}

Hasil pengujian kadar air dengan perlakuan perbedaan konsentrasi garam dengan konsentrasi 2, 8, dan 14\% diperoleh hasil kadar air tertinggi didapat dari konsentrasi 2\% dengan nilai kadar air $38,42 \%$. Hasil kadar air terendah diperoleh dari konsentrasi $14 \%$ dengan nilai kadar air yaitu 35,10\% (Table 1). Berdasarkan hasil yang diperoleh, kadar air terbaik dari sampel terasi udang rebon adalah terasi dengan penambahan garam konsentrasi $14 \%$. Kadar air terasi yang semakin rendah, maka terasi semakin awet. Hasil kadar air terasi pada penelitian ini sesuai dengan SNI terasi udang dengan nomor SNI 2716: 2016 (BSN 2016), bahwa kadar air terasi udang maksimal 45\% untuk terasi pasta, maksimal 35\% untuk terasi kering padat blok, dan maksimal $10 \%$ untuk terasi kering serbuk dan granula. 
Garam dalam proses fermentasi terasi udang rebon memegang peranan penting dalam parameter kadar air. Kadar air akan semakin rendah jika konsentrasi garam yang digunakan semakin tinggi. Kadar garam yang tinggi akan menyebabkan tekanan osmotik yang tinggi dan penurunan aktivitas air sehingga mikroorganisme tidak dapat tumbuh, sehingga garam berperan dalam mengawetkan produk terasi. Semakin tinggi konsentrasi garam maka kadar air semakin rendah, karena ion pada garam menarik molekul air, sehingga fermentasi dengan penggunaan garam mampu menurunkan kadar air. Hal ini sesuai dengan penelitian Karim et al. (2014) bahwa kadar air terasi diperoleh hasil 33,36\%-34,69\%. Romawati et al. (2014) juga menambahkan bahwa kadar air terasi udang rebon dengan penambahan konsentrasi garam 8,5\% mempunyai kadar air 34,56\%. Garam yang tinggi mampu menyerap kandungan air pada bahan pangan, sehingga penambahan kadar garam yang tinggi menghasilkan kadar air rendah.

\section{Uji Organoleptik Kenampakan}

Hasil uji organoleptik terhadap parameter kenampakan diperoleh terasi udang rebon dengan konsentrasi garam $2 \%$ dan $8 \%$ tidak berbeda nyata, dengan nilai masing-masing 8,93, sedangkan pada terasi dengan penambahan konsentrasi garam 14\% berbeda nyata dengan nilai 8,26 . Kenampakan terasi udang rebon adalah terasi tampak bersih dengan warna cokelat kemerahan (Table 2). Fermentasi dapat memengaruhi kenampakan terasi dan lama fermentasi dapat memengaruhi kenampakan terasi udang rebon. Lama fermentasi yang dilakukan yaitu 30 hari. Semakin lama waktu fermentasi, warna yang timbul pada terasi semakin gelap.
Bahan baku juga memengaruhi hasil akhir kenampakan dari terasi tersebut. Udang rebon akan menghasilkan warna yang baik pada terasi udang rebon. Menurut Ma'ruf (2013), terasi dibuat dari produk ikan kecil atau rebon melalui proses fermentasi. Penambahan garam pada terasi berfungsi sebagai pengawet. Terasi udang warnanya cenderung cokelat kemerahan sedangkan terasi ikan warnanya kehitaman. Selain itu, penambahan konsentrasi garam juga berpengaruh terhadap kenampakan terasi. Puspita et al. (2019) menyatakan bahwa penambahan konsentrasi garam yang semakin tinggi dapat memudarkan warna.

\section{Bau}

Uji organoleptik terhadap parameter bau pada terasi udang rebon menunjukkan hasil yang tidak berbeda nyata. Terasi udang rebon yang dihasilkan mempunyai bau sangat spesifik terasi udang. Aroma yang timbul pada terasi udang rebon disebabkan dari proses fermentasi. Selama proses fermentasi, mikroba dapat melakukan perubahan perubahan kimia membentuk senyawa volatil yang menyebabkan bau khas pada terasi. Menurut Suwandi et al. (2017), senyawa volatil pada terasi dihasilkan dari proses fermentasi yang menyebabkan transformasi senyawa kimia oleh mikroba. Aroma terasi dihasilkan dari 16 macam senyawa hidrokarbon, 7 macam alkohol, 46 karbonil, 7 macam lemak, 34 senyawa nitrogen, 15 macam senyawa belerang, dan senyawa lain.

\section{Rasa}

Hasil uji organoleptik terhadap parameter rasa pada terasi udang rebon dengan penambahan konsentrasi garam $2 \%$ dan $8 \%$ tidak berbeda nyata dengan nilai masing-masing 8,60 dan 8,00 . Nilai ini berbeda nyata dengan terasi udang rebon

Table 2 Organoleptic of Rebon Shrimp Paste

\begin{tabular}{lccc}
\hline \multicolumn{1}{c}{ Parameter } & $\mathrm{A}$ & $\mathrm{B}$ & $\mathrm{C}$ \\
\hline Appearance & $8.93 \pm 0.30^{\mathrm{a}}$ & $8.93 \pm 0.30^{\mathrm{a}}$ & $8.26 \pm 0.90^{\mathrm{b}}$ \\
Smell & $8.40 \pm 0.90 \mathrm{a}$ & $8.20 \pm 0.90^{\mathrm{a}}$ & $8.00 \pm 1.00^{\mathrm{a}}$ \\
Taste & $8.60 \pm 0.80^{\mathrm{a}}$ & $8.00 \pm 1.00^{\mathrm{a}}$ & $7.40 \pm 0.80^{\mathrm{b}}$ \\
Texture & $8.93 \pm 0.30^{\mathrm{a}}$ & $8.60 \pm 0.80^{\mathrm{ab}}$ & $7.13 \pm 1.40^{\mathrm{b}}$ \\
\hline
\end{tabular}

Information: different letter in same row indicate a significant difference 
dengan penambahan konsentrasi garam 14\% dengan nilai 7,40 (Table 2). Terasi udang rebon yang dihasilkan mempunyai rasa spesifik terasi udang. Terasi udang rebon dengan penambahan konsentrasi garam 14\% mengalami penurunan nilai organoleptik karena terasi mempunyai rasa asin akibat tingginya garam yang digunakan. Rasa yang timbul dalam terasi ditimbulkan karena asam-asam amino yang terbentuk selama fermentasi. Karim et al. (2014) menyatakan bahwa konsumen menyukai terasi dengan rebon sebagai bahan bakunya. Asam amino pada rebon merupakan sumber rasa gurih dari produk akhir terasi. Hadiwiyoto (1993) menyatakan bahwa asam amino akan mengalami peningkatan selama proses fermentasi karena pemecahan protein, sehingga cita rasa semakin enak jika kandungan asam aminonya tinggi.

\section{Tekstur}

Hasil uji organoleptik terhadap parameter tekstur dengan perbedaan konsentrasi garam diperoleh nilai rata rata tertinggi adalah konsentrasi 2\% dengan nilai 8,90 dengan spesifikasi terasi kompak. Nilai rata rata terendah adalah konsentrasi $14 \%$ dengan nilai 7,10 dengan spesifikasi terasi padat kurang kompak. Tekstur terasi dapat terbentuk melalui proses penjemuran dan penumbukan, yang akan memengaruhi nilai kadar air dan teksturnya. Penambahan garam juga akan memengaruhi tekstur karena garam mengikat air dan dapat menyebabkan tekstur terasi menjadi kompak. Nooryantini et al. (2012) menyatakan bahwa penjemuran dan penumbukan akan mempengaruhi tekstur terasi. Penjemuran akan memudahkan penumbukan terasi sehingga kualitas adonan berpengaruh terhadap tekstur terasi. Peningkatan nilai tekstur bertambah seiring lamanya fermentasi. Pembentukan tekstur dipengaruhi oleh penanganan bahan sebelum fermentasi yaitu tahapan penjemuran dan penumbukan.

\section{KESIMPULAN}

Penambahan konsentrasi garam berpengaruh terhadap karakteristik terasi udang rebon yang dihasilkan. Terasi dengan penambahan konsentrasi garam 2\% mempunyai nilai sensori terbaik dengan selang kepercayaan $8,6<\mu<8,8$.

\section{UCAPAN TERIMA KASIH}

Peneliti mengucapkan terima kasih kepada Universitas Diponegoro yang telah membiayai penelitian ini melalui skema Penguatan Komoditi Unggulan Masyarakat tahun anggaran 2020.

\section{DAFTAR PUSTAKA}

Akbar PP, Solichin A, Saputra SW. 2013. Analisis panjang-berat dan faktor kondisi pada udang rebon (Acetes japonicus) di Perairan Cilacap, Jawa Tengah. Journal of Management of Aquatic Resources. 2(3): 161-169.

Anggo, AD, Swastawati F, Ma'aruf WF, Rianingsih L. 2014. Mutu organoleptik dan kimiawi terasi udang rebon dengan kadar garam berbeda dan lama fermentasi. Jurnal Pengolahan Hasil Perikanan Indonesia. 17(1): 53-59.

[AOAC] Association of Official Analytical Chemists. 2005. Official Methods of Analiysis. Washington (DC): Benjamin Franklin Station.

Aprodita N. 2018. Pengaruh penambahan tepung udang rebon pada pembuatan serundeng terhadap daya terima konsumen. [SKRIPSI]. Jakarta (ID): Universitas Negeri Jakarta.

Aristyan I, Ibrahim R, Rianingsih L. 2014. Pengaruh perbedaan kadar garam terhadap mutu organoleptik dan mikrobiologis terasi rebon (Acetes sp.). Jurnal Pengolahan dan Bioteknologi Hasil Perikanan. 3(2): 60-66.

[BSN] Badan Standardisasi Nasional. 2006. Standar Nasional Indonesia (SNI). SNI01-2354.2-2006. Cara uji kimia - bagian 2: penentuan kadar air produk perikanan. Jakarta (ID): Badan Standardisasi Nasional.

[BSN] Badan Standardisasi Nasional. 2016. Standar Nasional Indonesia (SNI). SNI 2716: 2016. Terasi Udang. Jakarta (ID): Badan Standardisasi Nasional. 
Hadiwiyoto, S. 1993. Teknologi Pengolahan Hasil Perikanan jilid 1. Yogyakarta (ID): Liberty.

Joni LS, Erina, Abrar M. 2018. Total bakteri asam laktat (BAL) pada feses rusa sambar (Cervus unicolor) di Taman Rusa Aceh Besar. Jurnal Ilmiah Mahasiswa Veteriner. 2(1): 77-85.

Karim FA, Swastawati F, Anggo AD. 2014. Pengaruh perbedaan bahan baku terhadap kandungan asam glutamat pada terasi. Jurnal Pengolahan dan Bioteknologi Hasil Perikanan. 3(4): 51-58.

Khokani K, Ram V, Bhatt J, Khatri T, Joshi H. 2012. Spectrophotometric and chromatographic analysis of amino acids present in leaves of Ailanthus excelsa. International Journal of ChemTech Research. 4(1): 389-393.

Kristianawati F, Ibrahim R, Rianingsih L. 2014. Penambahan enzim yang berbeda pada pengolahan kecap ikan dari isi rongga perut ikan manyung (Arius thalassinus) terhadap mutu produk. Jurnal Saintek Perikanan. 9(2): 24-32.

Ma'ruf M, Sukarti K, Purnamasari E, Sulistianto. 2013. Penerapan produk bersih pada pengolahan terasi skala rumah tangga di Dusun Selangan Laut Pesisir Bontang. Jurnal Ilmu Perikanan Tropis. 18 (2): 84-93.

Majid A, Agustini TW, Rianingsih L. 2014. Pengaruh perbedaan konsentrasi garam terhadap mutu sensori dan kandungan senyawa volatil pada terasi ikan teri (Stolephorus sp). Jurnal Pengolahan dan Bioteknologi Hasil Perikanan. 3(2): 17-24.

Nooryantini S, Yuspihana F, Rita K. 2012. Kualitas terasi udang dengan suplementasi Pediococcus halophilus. Jurnal Hasil Perikanan Universitas Lambung Mangkurat: 12-27.

Putri RMS, Nurjanah, Tarman K. 2018. Pendugaan umur simpan serbuk minuman fungsional lintah laut (Discodoris sp) dengan metode Accelerated Shelf Life Test (ASLT) model Arhennius. MARINADE. 1(1): 45-55.

Puspita DA, Agustini TW, Purnamayati L. 2019. Pengaruh perbedaan konsentrasi garam terhadap kadar asam glutamat pada bubuk bekasam ikan lele (Clarias batracus). Jurnal Teknologi Pangan. 3(1): 110-115.

Rahmayati R, Riyadi PH, Rianingsih L. 2014. Perbedaan konsentrasi garam terhadap pembentukan warna terasi udang rebon (Acetes Sp.) basah. Jurnal Pengolahan dan Bioteknologi Hasil Perikanan. 3(1): 108117.

Romadhon, Rianingsih L, Anggo AD. 2018. Aktivitas antibakteri dari beberapa tingkatan mutu terasi udang rebon. Jurnal Pengolahan Hasil Perikanan Indonesia.21 (1): 68-76.

Romawati DW, Ma'ruf WF, Romadhon. 2014. Pengaruh kadar garam terhadap kandungan histamin, B12 dan nitrogen bebas terasi ikan teri (Stolephorus sp). Jurnal Pengolahan dan Bioteknologi Hasil Perikanan. 3 (1): 80-88.

Sanjaya YD, Sumardianto, Riyadi PH. 2016. Pengaruh penambahan ekstrak rosella (Hibiscus sabdariffa linn.) terhadap warna dan kualitas pada terasi udang rebon (Acetes sp.). Jurnal Pengolahan dan Bioteknologi Hasil Perikanan. 5(2): 1-9.

Sumardianto, Wijayanti I, Swastawati F. 2019. Karakteristik fisikokimia dan mikrobiologi terasi udang rebon Dengan variasi konsentrasi gula merah. Jurnal Pengolahan Hasil Perikanan Indonesia. 22(2): 287-298.

Suwandi, Rohanah A, Rindang A. 2017. Uji komposisi bahan baku terasi menggunakan alat percetakan terasi. Jurnal Rekayasa Pangan dan Pertanian. 5: 196-201.

Thariq AS, Swastawati F, Surti T. 2014. Pengaruh perbedaan konsentrasi garam pada peda ikan kembung (Rastrelliger negletus) terhadap kandungan asam glutamat pemberi rasa gurih (umami). Jurnal Pengolahan dan Bioteknologi Hasil Perikanan. 3(3): 104-111.

Ukhty N, Rozi A, Sartiwi A. 2017. Mutu kimiawi terasi dengan formulasi udang rebon (Acetes sp.) dan ikan rucah yang berbeda. Jurnal Perikanan Tropis. 4(2): 166-176. 
Wenno MR, Loppies CRM. 2019. Physicochemical characteristics and amino acid profile of fermented sauce made from tuna loin by-product. IOP Conf. Series: Earth and Environmental Science. 370:17.
Yuliana N. 2007. Perubahan karakteristik biokimia fermentasi tempoyak menggunakan Pediococcus acidilactici pada tiga tingkat konsentrasi gula. Agritech. 27(2): 83-88. 